Ç.Ü. Sosyal Bilimler Enstitüsü Dergisi, Cilt 28, Sayı 2, 2019, Sayfa 179-197

\title{
FUZZY ANALYTIC HIERARCHY PROCESS AND TOPSIS FOR PART-TIME STUDENT SELECTION
}

\author{
Mert DEMIRCİĞLU ${ }^{1}$ \\ Erkan TIYEKLI ${ }^{2}$
}

\begin{abstract}
The object of this study is about offering possible solutions to deal with the problems emerged in the selection of students working part-time in higher education institutions. University students are employed in accordance with their class hours according to the procedures and principles of part-time student work in higher education institutions in certain units of university. These students are employed in temporary jobs in their spare times besides their education hours according to their interests and skills contributing to their growth as productive individuals with discipline by providing both financial gain and application skills. Universities may encounter more demands than their needs whether they carry certain criteria for working in designated units. There may be unjustness in selection of the most suitable student due to these demands. In this study, a software was developed for assigning these parttime students applied to work on the web environment by using the Fuzzy Analytic Hierarchy Process (F-AHP) method. Using TOPSIS software developed and with this software has been shown to accomplish a fairer choice than the other available part-time student selection tool currently used.

Keywords: Fuzzy Analytic Hierarchy Process (F-AHP), TOPSIS, Part-Time Student Selection
\end{abstract}

\section{YARI ZAMANLI ÖĞRENCI SEÇIMIINDE BULANIK ANALITIK HIYYERARŞİ SÜRECİ VE TOPSIS}

ÖZ

$\mathrm{Bu}$ çalışma yükseköğretim kurumlarında kısmi zamanlı olarak çalıştırılan öğrencilerin seçimi ile ilgilidir. Yükseköğretim kurumları kısmi zamanlı öğrenci çalıştırma usul ve esaslarına göre üniversitelerde öğrenciler üniversitelerin belirli birimlerinde ders saatlerine uygun olarak çalıştırılmaktadırlar. Bu öğrenciler, ders saati dışındaki boş zamanlarında ilgi ve yetenekleri doğrultusunda geçici işlerde çalıştırılarak hem maddi kazanç hem de uygulama becerisi kazanmaları sağlanır ve iş disiplini edinmiş üretken bireyler olarak yetişmelerine katkıda bulunulması amaçlanır. Üniversiteler ihtiyacı belirlenmiş birimlerinde çalıştırılmak üzere belirli kriterlerde talepler oluşturduklarında, ihtiyaçtan fazla öğrenci talebi ile karşılaşabilir. Bu talepler içerisinde ihtiyaca en uygun öğrenci seçiminde belirsizlikler yaşanabilir. Araştırmada Bulanık Analitik Hiyerarşi Süreci (BAHP) yöntemini uygulanarak kriterlerin belirletildiği, İdeal çözüme benzerlik yoluyla tercih sıralama tekniği (TOPSIS) yöntemi uygulanarak da sıralamanın yapıldığı bir yazılım geliştirilmiş ve web ortamında çalışacak şekilde yarı zamanlı öğrencilerin seçiminde kullanılmıştır. Geliştirilen yazılımın, mevcut kullanılan yarı zamanlı öğrenci seçimi araçlarından daha adil seçim yaptığı görülmüştür.

${ }^{1}$ Dr. Öğr. Üyesi, Çukurova Üniversitesi, İ.İ.B.F., İşletme Bölümü, mdemircioglu @ cu.edu.tr, ORCID: 0000-00022287-2067.

${ }^{2}$ Doktora Öğrencisi, Çukurova Üniversitesi, Sosyal Bilimler Enstitüsü, İşletme Anabilim Dalı, etiyekli@cu.edu.tr, ORCID: 0000-0003-1907-5670.

Recieved/Geliş: 17/06/2019 Accepted/Kabul:05/09/2019, Research Article/Araştırma Makalesi

Cite as/Alıntı: Demircioğlu, M. ve Tikyeli, E. (2019), "Fuzzy Analytic Hierarchy Process and Topsis for Part-Time Student Selection”, Çukurova Üniversitesi Sosyal Bilimler Enstitüsü Dergisi, cilt 28, sayı 2, s.179-197. 
Ç.Ü. Sosyal Bilimler Enstitüsü Dergisi, Cilt 28, Sayı 2, 2019, Sayfa 179-197

Anahtar Kelimeler: Bulanık Analitik Hiyerarşi Süreci (BAHP), TOPSIS, Yarı Zamanlı Öğrenci Seçimi

\section{Introduction}

In today's modern information age, hiring qualified employees is an important issue. In order to survive and compete with the other companies in the market, companies need workers who are eligible for the job requirements. The fact that the number of the applicants who are in need of work far surpasses the number of employees needed is one of the frequently encountered problems nowadays. The decision to appropriately choose the personnel to meet the necessary demand is of utmost importance in terms of equipping the company with qualified labor force. This process can be described as the identification of candidates with the best qualifications to fit the job requirements. In this process, all applicants are evaluated based on the criteria designating the job requirements and then those displaying the highest eligibility for these job requirements are preferred.

Companies should have access to eligible and qualified applicants to employ for the required positions and to establish and apply this selection process effectively and properly to enable the identification of the appropriate staff for the required job (Erdoğan, 1991). Companies need an employee selection process to determine their requirements. In this selection process, the criteria required to choose the personnel are determined and subsequent evaluation needs to be conducted.

In the present study, multi-criteria decision-making techniques have been applied in order to solve the problem of not assigning the right job to the right person. For this purpose, in this study, which criteria have been taken into consideration in the selection of the students who work for Cukurova University Health, Culture and Sport Department will be investigated.

An average of 7000 students apply annually to the application system designed for the students at Cukurova University to work part-time and approximately 500 of them are employed each year. These students will be employed in temporary jobs in their spare time outside their class hours to gain both financial support and practical skills, and to contribute to their growth as productive individuals with professional discipline. When universities create demands, based on certain criteria, for students to be employed in previously designated units, they may face more applications than they need. There may be ambiguities in the selection of the most suitable students to meet the demand.

The aim of this study is to use the Fuzzy Analytic Hierarchy Process (FAHP) method which is one of the multi-criteria decision-making methods and applied in many different fields in the literature to solve the problem of selecting the students to be employed part-time at Cukurova University and to measure the effectiveness of this method.

This system which will be web-based ensures that students will be able to see the announced job vacancies instantaneously. They will also be able to see the job announcements that they have applied to by using FAHP together with other applicants who applied to them. 
This way, a ranking will be made based on Technique for Order Preference by Similarity to Ideal Solution (TOPSIS) and thus a fair selection procedure will be followed for the selection of the right students. The ranking of the students who apply after the job announcements for the required units will also be important from the point of view that the jobs will be ranked from the most urgent to the least ones.

The software prepared for Health Culture and Sports Department Administration and the users of the part time student unit is prepared for Cukurova University and since the parameters used could be added or modified, it can be used for other universities as well.

\section{Multiple Criteria Decision-Making Techniques}

Decision-making is the process of determining and selecting alternatives based on the decision-maker's values and preferences (Fülop, 2019). Knowing that there are alternative options to consider is not only about determining as many of these alternatives as possible, but also about choosing the ones that best suit our goals, desires, and values.

Analytic Hierarchy Process (AHP) is a multi-criteria decision-making technique that addresses problems in a hierarchical structure and relies on the dual comparative logic (Felek, Yurdakul, \& Aladağ, 2007). The ability of the AHP to take subjective criteria into account when making multi-criteria decisions by decision makers is one of its most important features. With the utilization of fuzzy logic / numbers in the evaluation of the strengths and alternatives of the criteria, it is possible to incorporate the uncertainties of human expressions and the modeling of the subjectivities with a newer method, Fuzzy AHP.

Qualitative factors have major prominence in AHP, which is a multi-criteria decisionmaking approach. It is a technique that can combine qualitative and quantitative factors in the detailed evaluation of alternatives. AHP is used to assess the factors that are independent of each other at various levels in their hierarchical structure (Anık, 2007). The problem is structured in a hierarchical way in AHP. A three-level hierarchical structure is shown in Figure 1. At the top of the hierarchy, there is a goal and the structure is completed in the way that the criteria and alternatives are at the bottom. In AHP, the problem that constitutes the essence of the decision-making problem is organized in a hierarchical structure separated by its components (Saaty \& Vargas, 2001).

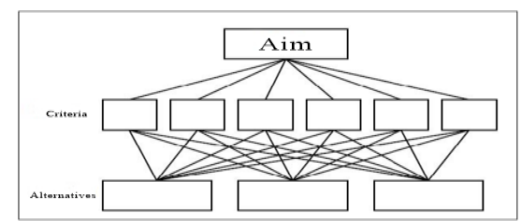

Method

Figure 1. Three-Level Analytic Hierarchy Model

Multi criteria decision making methods will be used to determine the students who apply to the offers advertised for units of Cukurova University Department of Health Culture and Sports. A software was developed by using the FAHP and TOPSIS. This software will be 
applied and the results will be evaluated. This software is coded in ASP (Active Server Page) language (developed by Microsoft for web applications and basic level HTML / XHTML and any scripting language JavaScript - VBScript should be known). The software is designed as separate modules for administrators and students (Figure 2).

The scope of the research is the request of the units of the Cukurova University which provide part-time jobs for students. Also, the application data which exist in the unit web site that students want to work as "Part-time Students" constitute the scope of the research. The sampling comprises two students who applied for two positions advertised by Cukurova Department of Health, Culture and Sports: one student who applied for 'computer maintenance related to Health, Culture and Sports Department' and the other student who applied for 'using certain software, updating and taking pictures'.

The criteria which are determined by Cukurova University Department of Health Culture and Sports will be used for selecting the students who applied for the job and are in need of it. Data were gathered from the half-time scholarship module via the official website of Cukurova University Department of Health Culture and Sports. Once the necessary information was computerized, the information in the system's database was used numerically.

Students use their user name and password to enter "General Criteria" which exist in the Half-Time Student Application Module of the official website of Cukurova University Department of Health Culture and Sports. After that, students can apply for the job offers that are specified by the units if the system approves that there is no incorrect or incomplete information on the part of the student. The data from the database in the form of access mdb, which is the database of these data, will be used by the computer environment. The asp (active server page) remodeled by FAHP and TOPSIS method will be calculated with the files encoded with web language. In this model (Figure 3 ) the consistency check of the criteria will be made and checked.

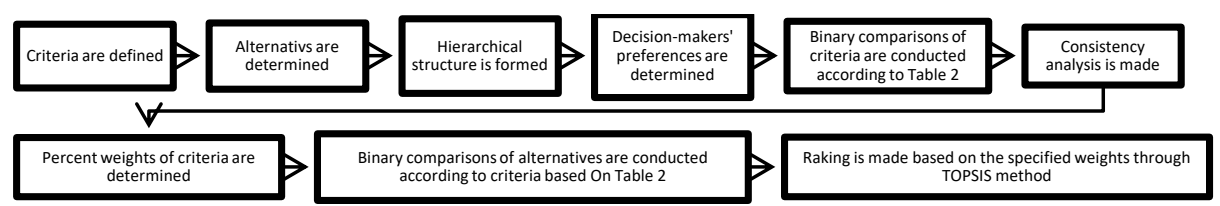

Figure 3. FAHP and TOPSIS Steps in Developed Software

\section{General Criteria Used}

These criteria are determined by the management and will be used by the units to find the person who is in need and applies for the job.

Criteria 1) Learning Mode

Criteria 2) Scholarship Earned

Criteria 3) Disciplinary Punishment

Criteria 4) Mother - Father (Alive - Together, Alive - Divorced, one or two

are dead)

Criteria 5) Family Residence (own house, rent)
Criteria 6) Family Vehicle (there is, there is not)

Criteria 7) Mother's Salary (high, moderate, low, very low, unemployed)

Criteria 8) Father's Salary (high, moderate, low, very low, unemployed)

Criteria 9) Number of Brother / Sister on Education (Primary School)

Criteria 10) Number of Brother / Sister on Education (High School)

Criteria 11) Number of Brother / Sister on Education (Universit 


\section{Ç.Ü. Sosyal Bilimler Enstitüsü Dergisi, Cilt 28, Sayı 2, 2019, Sayfa 179-197}

The criteria specified are the general criteria for which weights are calculated with FAHP as standard for each student to work for part time. The units that will provide job offers will be able to use 5 different importance levels while creating their own criteria. These criteria will be determined based on the relative importance in Table 1. In this case, the criteria added by the unit will have a weight with a software made besides the standard criteria to be used. In this weighing process, the scoring and ranking of students' responses according to these criteria will lead to a different result than scoring and ranking of students' responses according to standard criteria.

\section{The Current Scoring System}

The scores assigned to the alternatives of each criteria in the current scoring system are shown in Table 1.

Table 1. Scoring of Currently Used Criteria

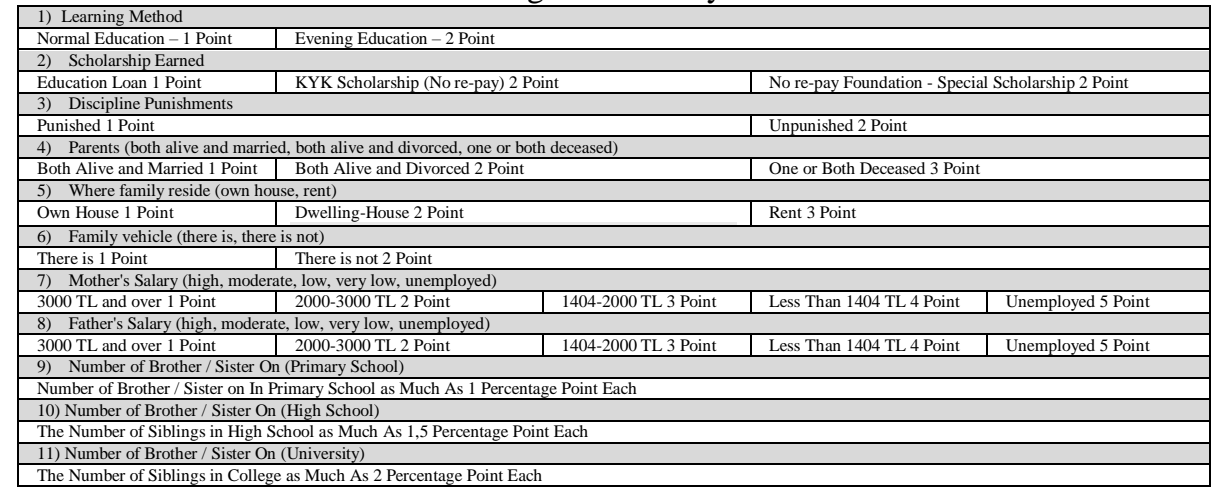

In this process, there is no relation between the criteria. Certain scores have been assigned to alternatives created for each criteria. The students who applied to the system are given the alternative scores indicated for each criteria according to their characteristics. For example, the steps of the process for the selection of the student to be employed in Cukurova University Student Activities Unit's 'creation, processing and editing of visual designs' post are given in Figure 4. 
Ç.Ü. Sosyal Bilimler Enstitüsü Dergisi, Cilt 28, Sayı 2, 2019, Sayfa 179-197

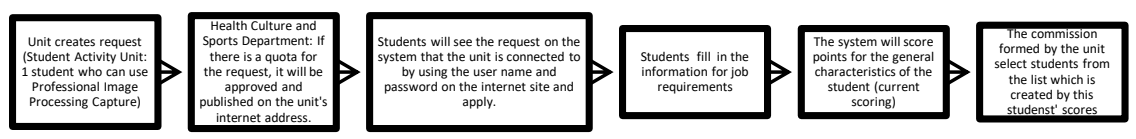

Figure 4. Current Student Selection Flowchart

\section{FAHP Scoring System}

Many scientists have been interested in the blurred extension of Saaty's priority theory. Since the publication of The Analytic Hierarchy Process (AHP) by Saaty, Dutch academics Van Laarhoven and Pedrycg have proposed a method in which the fuzzy comparison decision is represented by triangular fuzzy numbers. Priority vectors were obtained for the logarithmic least square's method (for Short LLMS) (Chang, 1996).

Since basic AHP does not contain ambiguity for individual decisions, it has been developed using the fuzzy logic approach. In fuzzy AHP, comparisons of both criteria and alternatives are performed by linguistic variables represented by triangular numbers. The first fuzzy AHP applications were carried out by Van Laarhoven and Pedrycz (Laarhoven, 1983). Later, Buckley contributed to the issue by setting blurred priorities in comparison ratios with triangular membership functions. Chang has also introduced a new method of using triangular numbers in double comparisons.

The comparative matrices of the general criteria and alternatives to be used in the new system have been developed and presented to the Department of Health, Culture and Sports (management) and approved. In this process, the relations between the criteria and the relations between the alternatives are also made with FAHP. When the units are to add new criteria other than the general criteria, they will state the relationships between the criteria and the alternative. The system will weigh the relationships between these new criteria and alternatives with the general criteria and alternatives according to the comparison determined by the unit. For example, the steps of the process for the selection of the student to be employed in Cukurova University Student Activities Unit's 'creation, processing and editing of visual designs' post are given in Figure 5. 
Ç.Ü. Sosyal Bilimler Enstitüsü Dergisi, Cilt 28, Sayı 2, 2019, Sayfa 179-197

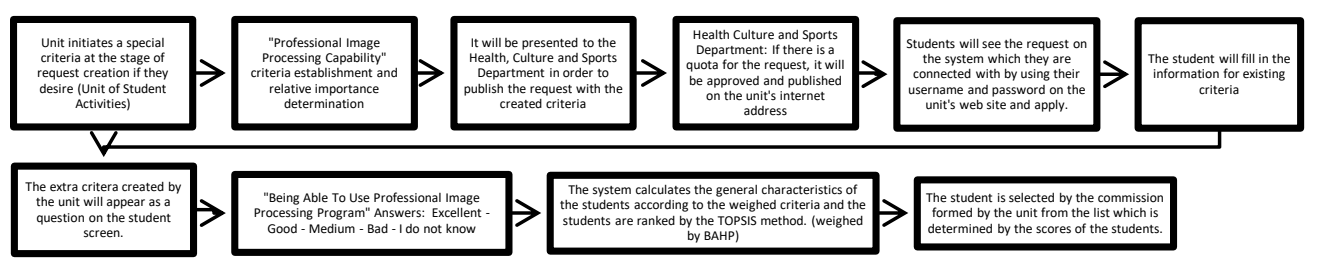

Figure 5. Flowchart of the New System

Calculation of Priority of Fuzzy AHP

In fuzzy numbers, $A=\left(a_{i j}\right)_{n \times m}$ is the fuzzy pair comparison matrix, here $\left.a_{i j}=l_{i j}, m_{i j}, u_{i j}\right)$ are

$$
l_{i j}=\frac{1}{l_{j i}}, m_{i j}=\frac{1}{m_{j i}}, u_{i j}=\frac{1}{u_{j i}}
$$

To obtain estimates for weight vectors under each criteria, we must consider the principle of comparing fuzzy numbers. We will give the definition as follows (Table 2).

Table 2. Linguistic terms and corresponding triangular fuzzy numbers

\begin{tabular}{|l|l|l|}
\hline Saaty Scale & Definition & Fuzzy Triangle Scale \\
\hline 1 & Equally Important, Equally Contributing to The Two Criteria & $(1,1,1)$ \\
\hline 3 & A Criteria Has A Little More Contribution Relative to The Other & $(2,3,4)$ \\
\hline 5 & A Criteria Has More Contribution Relative to The Other & $(4,5,6)$ \\
\hline 7 & A Criteria Has Much More Contribution Relative to The Other. & $(6,7,8)$ \\
\hline 9 & A Criteria Has the Most Contribution Relative to The Other. & $(9,9,9)$ \\
\hline & & $(1,2,3)$ \\
& \multirow{3}{*}{ Interval values between two adjacent scales } & $(3,4,5)$ \\
\cline { 3 - 3 } & & $(5,6,7)$ \\
\hline 6 & & $(7,8,9)$ \\
\hline 8 & & \\
\end{tabular}

Based on these linguistic terms referring to the corresponding triangular fuzzy numbers, the fuzzy triangle scale is $(2,3,4)$, for example, if the decision maker says "Criteria 1 (C1) Criteria 2 (C2) Weak Important". On the contrary, if $\mathrm{C} 2$ is compared with $\mathrm{C} 1$ in the binary contribution matrix of the criteria, the fuzzy triangle scale becomes (1/4, 1/3, 1/2) (Ayhan, 2013).

\section{Presentation Method of Fuzzy Numbers for the Dual Comparison Scale}

The first task of the fuzzy AHP method is to determine the relative importance of both factor pairs in the same hierarchy. By using triangular fuzzy numbers, the fuzzy evaluation matrix $A=\left(a_{i j}\right)_{n \times m}$ is generated by double comparison.

$$
a_{i j}^{-1}=\left(\frac{1}{u}, \frac{1}{m}, \frac{1}{l}\right)
$$


Ç.Ü. Sosyal Bilimler Enstitüsü Dergisi, Cilt 28, Sayı 2, 2019, Sayfa 179-197

Definition 1: $M \in F(R)$ If the fuzzy number is called:

1) $X_{0} \in R$ for that $\mu_{M}\left(X_{0}\right)=1$

2) any $\propto \in[0,1]$

$A_{\alpha}=\left[x, \mu_{A_{\alpha}}(x) \geq \alpha\right]$ It is a closed interval. $F(R)$ represents all fuzzy clusters and $R$ is a real number cluster.

Definition 2: If the membership function is equal to $\mu_{M}(x): R \rightarrow[0,1]$, we define a fuzzy $M$ on $R$ as a triangle fuzzy number.

$$
\mu_{M}(x)=\left\{\begin{array}{rr}
\frac{x}{m-1}-\frac{1}{m-1}, & x \in[1, m], \\
\frac{x}{m-u}-\frac{u}{m-u}, & x \in[m, u], \\
0, & \text { Otherwise, }
\end{array}\right.
$$

$1 \leq m \leq u, 1$ and $u$ are the upper and lower values of the $M$ support, respectively, and $M$ for the modal value. The triangular fuzzy number can be denoted by $(l, m, u)$. The support of $M$ is a set of elements $R\{x \in R \mid l<x<u\}$. When $1=\mathrm{m}=\mathrm{u}$, the numbers are not blurred (Chang, 1996).

If two positive fuzzy numbers are defined as $M_{1}=\left(l_{1}, m_{1}, u_{1}\right)$ and $M_{2}=\left(l_{2}, m_{2}, u_{2}\right)$, then the addition and multiplication operations of these two triangular fuzzy numbers will be as shown in the following equations (Chang, 1996).

$$
M_{1}+M_{2}=\left(l_{1}+l_{2}, m_{1}+m_{2}, u_{1}+u_{2}\right) \quad M_{1} \times M_{2}=\left(l_{1} \times l_{2}, m_{1} \times m_{2}, u_{1} \times u_{2}\right)
$$

Each object is handled to realize a goal, with a set of objects $\mathrm{Xn}=1,2, \ldots, \mathrm{n}$ and a set of objects at $\mathrm{Um}=1,2, \ldots, \mathrm{m}$. Thus, $\mathrm{m}$ expanded analytical values are obtained and are shown as follows:

$$
M_{g i_{i}}^{1}, M_{g i_{i}}^{2}, \ldots \ldots \ldots M_{g i_{i}}^{m} \quad \mathrm{i}=1,2, \ldots \ldots, \mathrm{n}
$$

All $M$ values are triangular fuzzy numbers $M_{g i_{i}}^{j} \quad(\mathrm{j}=1,2, \ldots, \mathrm{m})$ (Chang, 1996)

Definition 3: Let $M$ be the scope analysis of the $i$. Then in the context of fuzzy synthetic, the value relative to the $i^{\text {th }}$ object is:

$$
S_{i}=\sum_{j=1}^{m} M_{g_{i}}^{j} \times\left[\sum_{i=1}^{n} \sum_{j=1}^{m} M_{g_{i}}^{j}\right]^{-1}
$$

In Table 3, the criteria were evaluated according to the comparative matrix in Table 4 within the knowledge of Cukurova University Health and Culture Department. At this stage, the binary relations of criteria and weight values are determined. 
Ç.Ü. Sosyal Bilimler Enstitüsü Dergisi, Cilt 28, Sayı 2, 2019, Sayfa 179-197

Table 3. Comparative Matrix of General Criteria to be Used

\begin{tabular}{|c|c|c|c|c|c|c|c|c|c|c|c|}
\hline Criteria to be used & Criteria 1 & Criteria 2 & Criteria 3 & Criteria 4 & Criteria 5 & Criteria 6 & Criteria 7 & Criteria 8 & Criteria 9 & Criteria 10 & Criteria 11 \\
\hline $\begin{array}{l}\text { Criteria } 1 \\
\end{array}$ & $1,1,1$ & $1 / 8,1 / 7,1 / 6$ & $1 / 8,1 / 7,1 / 6$ & $1 / 6,1 / 5,1 / 4$ & $1 / 4,1 / 3,1 / 2$ & $1 / 4,1 / 3,1 / 2$ & \begin{tabular}{|l}
$1 / 8,1 / 7,1 / 6$ \\
\end{tabular} & $1 / 6,1 / 5,1 / 4$ & $1 / 4,1 / 3,1 / 2$ & $1 / 4,1 / 3,1 / 2$ & $1 / 8,1 / 7,1 / 6$ \\
\hline Criteria 2 & $6,7,8$ & $1,1,1$ & $1,1,1$ & $1,1,1$ & $2,3.4$ & $2,3,4$ & $2,3,4$ & $2,3.4$ & $2,3.4$ & $2,3,4$ & $1,1,1$ \\
\hline Criteria 3 & $6,7,8$ & $1,1,1$ & $1,1,1$ & $1,1,1$ & $2,3,4$ & $1,1,1$ & $1,1,1$ & $1,1,1$ & $2,3,4$ & $2,3,4$ & $1,1,1$ \\
\hline $\begin{array}{l}\text { Criteria } 4 \\
\end{array}$ & $4,5,6$ & $1,1,1$ & $1,1,1$ & $1,1,1$ & $2,3,4$ & $2,3,4$ & \begin{tabular}{|l|l}
$1 / 4,1 / 3,1 / 2$ \\
\end{tabular} & $1 / 4,1 / 3,1 / 2$ & $2,3,4$ & $4,5,6$ & $1 / 4,1 / 3,1 / 2$ \\
\hline Criteria 5 & \begin{tabular}{|l|}
$2,3,4$ \\
\end{tabular} & $1,1,1$ & $1 / 4,1 / 3,1 / 2$ & $1 / 4,1 / 3,1 / 2$ & $1,1,1$ & $2,3,4$ & $1 / 4,1 / 3,1 / 2$ & $1 / 4,1 / 3,1 / 2$ & $2,3,4$ & $2,3,4$ & $1 / 4,1 / 3,1 / 2$ \\
\hline $\begin{array}{l}\text { Criteria } 6 \\
\end{array}$ & $2,3,4$ & $1 / 4,1 / 3,1 / 2$ & $1,1,1$ & $1 / 4,1 / 3,1 / 2$ & $1 / 4,1 / 3,1 / 2$ & $1,1,1$ & $1 / 6,1 / 5,1 / 4$ & $1 / 6,1 / 5,1 / 4$ & $1,1,1$ & $1,1,1$ & $1 / 6,1 / 5,1 / 4$ \\
\hline $\begin{array}{l}\text { Criteriaa } 7 \\
\end{array}$ & \begin{tabular}{|l|l|}
$6,7,8$ \\
\end{tabular} & $1 / 4,1 / 3,1 / 2$ & $1,1,1$ & $2,3,4$ & $2,3,4$ & $4,5,6$ & $1,1,1$ & $2,3,4$ & $2,3,4$ & $2,3,4$ & $1 / 4,1 / 3,1 / 2$ \\
\hline $\begin{array}{l}\text { Criteria } 8 \\
\end{array}$ & $4,5,6$ & $1 / 4,1 / 3,1 / 2$ & $1,1,1$ & $2,3,4$ & $2,3,4$ & $4,5,6$ & \begin{tabular}{|l|l}
$1 / 4,1 / 3,1 / 2$ \\
\end{tabular} & $1,1,1$ & $2,3,4$ & $2,3,4$ & $1 / 6,1 / 5,1 / 4$ \\
\hline Criteria 9 & $2,3,4$ & $1 / 4,1 / 3,1 / 2$ & $1 / 4,1 / 3,1 / 2$ & $1 / 4,1 / 3,1 / 2$ & $1 / 4,1 / 3,1 / 2$ & $1,1,1$ & $1 / 4,1 / 3,1 / 2$ & $1 / 4,1 / 3,1 / 2$ & $1,1,1$ & $1,1,1$ & $1 / 6,1 / 5,1 / 4$ \\
\hline $\begin{array}{l}\text { Criteria } 10 \\
\end{array}$ & $2,3,4$ & $1 / 4,1 / 3,1 / 2$ & $1 / 4,1 / 3,1 / 2$ & $1 / 6,1 / 5,1 / 4$ & $1 / 4,1 / 3,1 / 2$ & $1,1,1$ & $1 / 4,1 / 3,1 / 2$ & $1 / 4,1 / 3,1 / 2$ & $1,1,1$ & $1,1,1$ & $1 / 6,1 / 5,1 / 4$ \\
\hline Criteria 11 & $6,7,8$ & $1,1,1$ & $1,1,1$ & $2,3,4$ & $2,3,4$ & $4,5,6$ & $2,3,4$ & $4,5,6$ & $4,5,6$ & $4,5,6$ & $1,1,1$ \\
\hline
\end{tabular}

In Table 3, the evaluations of the criteria in each column are assigned to variables $\mathrm{L}, \mathrm{M}$ and $\mathrm{U}$, and the sum of the values in each row is calculated and then written in the total lines in Table 4.

Definition 4: The probability level of $M_{1} \geq M_{2}$ is defined as follows:

$$
V\left(M_{1} \geq M_{2}\right)=\sup _{x \geq y}\left[\min \left(\mu_{M_{1}}(x), \mu_{M_{2}}(y)\right)\right]
$$

When there is a pair $(x, y)$ such that $\mu_{M_{1}}(x)=\mu_{M_{2}}(y)=1$ is, then $V\left(M_{1} \geq M_{2}\right)=1$ and $x \geq y \cdot M_{1}$ and $M_{2}$ are convex fuzzy numbers.

$$
V\left(M_{1} \geq M_{2}\right)=1 \text { if } m_{1} \geq m_{2}, \quad V\left(M_{2} \geq M_{1}\right)=h t g\left(M_{2} \cap M_{1}\right)=\mu_{M_{1}}(d),
$$

Where $d$ is the ordinate of the highest intersection point D between $\mu_{M_{1}}$ and $\mu_{M_{2}}$.

If $M_{1}=\left(l_{1}, m_{1}, u_{1}\right)$ and $M_{2}=\left(l_{2}, m_{2}, u_{2}\right)$, the ordinate of D is: $V\left(M_{2} \geq M_{1}\right)=h g t\left(M_{1} \cap M_{2}\right)=\frac{l_{1}-u_{2}}{\left(m_{2}-u_{2}\right)-\left(m_{1}-l_{1}\right)}$

We need values of $V\left(M_{1} \geq M_{2}\right)$ and $V\left(M_{2} \geq M_{1}\right)$ to compare $M_{1}$ and $M_{2}$ (Chang, 1996).

Definition 5: The probability that the convex fuzzy numbers are larger than the convex fuzzy numbers $M_{i}(i=1,2, \ldots, k)$ can be defined as:

$$
V\left(M \geq M_{1}, M_{2}, \ldots, M_{k}\right)=V\left[\left(M \geq M_{1}\right) \text { and } M \geq M_{2} \text { ve } \ldots . M \geq M_{k}=\min V\left(M \geq M_{i}\right), \quad i=1,2, \ldots, k\right.
$$

Assume That: $d^{\prime}\left(A_{i}\right)=\min V\left(S_{i} \geq S_{k}\right), k=1,2, \ldots, n ; k \neq i$ The weight vector, $W^{\prime}=$ $\left(d^{\prime}\left(A_{1}\right), d^{\prime}\left(A_{2}\right), \ldots, d^{\prime}\left(A_{n}\right)\right)^{T}, A_{i} \quad(i=1,2, \ldots, n) . n$ element weights are calculated. Then we obtain the weight vectors by normalization. $W=\left(d\left(A_{1}\right), d\left(A_{2}\right), \ldots, d\left(A_{n}\right)\right)^{T} W$ is a non-blurred number. For each criteria, the $S$ value was calculated by summing the $\mathrm{L}, \mathrm{M}$ and $\mathrm{U}$ totals calculated $\left(L_{\text {Sum }}=165.5, M_{\text {sum }}=212.37\right.$ ve $\left.U_{\text {sum }}=261.92\right)$ in Table 4 and the inverse $1 / L_{\text {sum }}=0.006042,1 / M_{\text {sum }}=$ 0.004709 and $1 / U_{\text {sum }}=0.003818$ totals. Calculation of the $\mathrm{L}, \mathrm{M}$ and $\mathrm{U}$ values for the $S$ values shown in Table 8 is given below for Criteria 1. It is calculated the same way for the other criteria. 
Ç.Ü. Sosyal Bilimler Enstitüsü Dergisi, Cilt 28, Sayı 2, 2019, Sayfa 179-197

Table 4. FAHP Weight Account of the Comparative Matrix of General Criteria to be Used Step 2

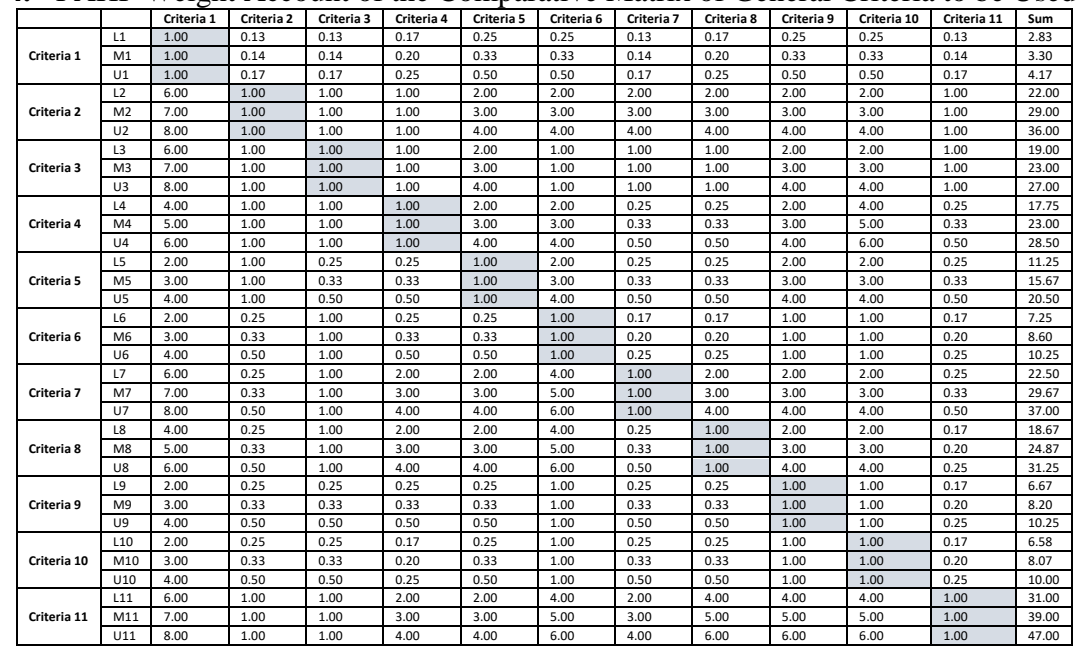

Criteria $L_{1}=L_{1} * \frac{1}{U_{\text {Sum }}}=2.83 \times 0.003818=0.0108$,
Criteria $M_{1}=M_{1} * \frac{1}{M_{\text {Sum }}}=3.30 \times 0.004709=0.0156$,
Criteria $U_{1}=U_{1} * \frac{1}{L_{\text {Sum }}}=4.17 \times 0.006042=0.0252$

Table 5. L, M and U Values for the FAHP S of the Comparative Matrix of General Criteria to be Used Step 3

\begin{tabular}{|c|c|c|c|}
\hline & & $M$ & U \\
\hline SCriteria 1 & 0.0108 & 0.0156 & 0.0252 \\
\hline SCriteria 2 & 0.0840 & 0.1366 & 0.2175 \\
\hline S Criteria 3 & 0.0725 & 0.1083 & 0.1631 \\
\hline SCriteria 4 & 0.0678 & 0.1083 & 0.1722 \\
\hline SCriteria 5 & 0.0430 & 0.0738 & 0.1239 \\
\hline SCriteria 6 & 0.0277 & 0.0405 & 0.0619 \\
\hline $\begin{array}{l}\text { SCriteria } 7 \\
\end{array}$ & 0.0859 & $\begin{array}{l}0.1397 \\
\end{array}$ & 0.2236 \\
\hline SCriteria 8 & 0.0713 & 0.1171 & 0.1888 \\
\hline SCriteria 9 & 0.0255 & 0.0386 & 0.0619 \\
\hline SCriteria 10 & 0.0251 & 0.0380 & 0.0604 \\
\hline SCriteria 11 & 0.1184 & 0.1836 & 0.2840 \\
\hline
\end{tabular}

For the values calculated in Table 5, for the probability values of $M_{1} \geq M_{2}, V\left(M_{1} \geq M_{2}\right)=1$ if 
$m_{1} \geq m_{2}$, otherwise $\frac{l_{1}-u_{2}}{\left(m_{2}-u_{2}\right)-\left(m_{1}-l_{1}\right)}$ the smallest $S$ values were calculated and reported in Table 6. Also, weights are determined by normalization of Min $\mathrm{S}$ values.

Table 6. S Probability Values of the Comparative Matrix of General Criteria to be Used Account and Weight Calculation Step 4

\begin{tabular}{|l|l|l|l|l|l|l|l|l|l|l|l|l|}
\hline & $\mathrm{s} 1$ & $\mathrm{~s} 2$ & $\mathrm{s3}$ & $\mathrm{s}$ & $\mathrm{s}$ & $\mathrm{s}$ & $\mathrm{s}$ & $\mathrm{s}$ & $\mathrm{s} 8$ & $\mathrm{~s} 9$ & $\mathrm{~s} 10$ & $\mathrm{~s} 11$ \\
\hline $\mathbf{1}$ & 0 & 1.000000 & 1 & 1 & 1 & 1 & 1 & 1 & 1 & 1 & 1 \\
\hline $\mathbf{2}$ & 0 & 1 & 0.736938 & 0.75741 & 0.388401 & 0 & 1 & 0.843406 & 0 & 0 & 1 \\
\hline $\mathbf{3}$ & 0 & 1 & 1 & 1 & 0.597805 & 0 & 1 & 1 & 0 & 0 & 1 \\
\hline $\mathbf{4}$ & 0 & 1 & 1 & 1 & 0.618985 & 0.00 & 1 & 1 & 0 & 0 & 1 \\
\hline $\mathbf{5}$ & 0 & 1 & 1 & 1 & 1 & 0.36323 & 1 & 1 & 0.350593 & 0.328041 & 1 \\
\hline $\mathbf{6}$ & 0 & 0.976705 & 0.711019 & 0.733273 & 0.365425 & 0 & 1 & 1 & 0.947878 & 0.928764 & 1 \\
\hline $\mathbf{7}$ & 0 & 1.00 & 0.912682 & 1 & 0.54836 & 0 & 1 & 0.819932 & 0 & 0 & 1 \\
\hline $\mathbf{8}$ & 0 & 1 & 1 & 1 & 1 & 1 & 1 & 1 & 0 & 0 & 1 \\
\hline $\mathbf{9}$ & 0.001826 & 1 & 1 & 1 & 1 & 1 & 1 & 1 & 1 & 0.982363 & 1 \\
\hline $\mathbf{1 0}$ & 0.00 & 0.678039 & 0.372814 & 0.416816 & 0.047745 & 0 & 0.705352 & 0.514281 & 0 & 0 & 1 \\
\hline The Smallest + value (w) & 0 & 0.678039 & 0.372814 & 0.416816 & 0.047745 & 0 & 0.705352 & 0.514281 & 0 & 0 & 1 \\
\hline Normalize (w') & 0.00 & 0.18 & 0.10 & 0.11 & 0.01 & 0.00 & 0.19 & 0.14 & 0.00 & 0.00 & 0.27 \\
\hline
\end{tabular}

Table 7 shows the weight of each criteria. These weights will be parametric values of the general criteria in the system after calculating the weights of the alternatives of the criteria and will be assigned automatically.

Table 7. FAHP weights of comparative matrix of general criteria to be used Line averages

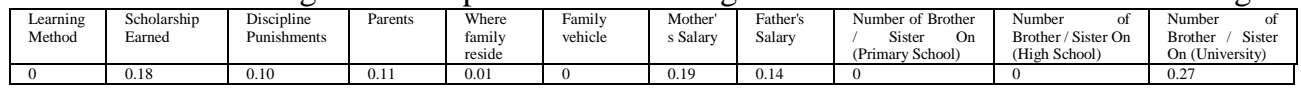

Table 8 shows the weights of alternatives of the general criteria. These weights are used in the system in which each criteria is weighed in Table 7 and in Table 8 the weight of alternatives in that criteria are synchronized and used in the calculation of the score of each student applying to the system.

Table 8. New Weighed General Criteria Table

\begin{tabular}{|c|c|c|c|c|c|c|c|c|c|c|c|}
\hline & \begin{tabular}{|l} 
Learning \\
Method
\end{tabular} & \begin{tabular}{|l}
$\begin{array}{l}\text { Scholarship } \\
\text { Earned }\end{array}$ \\
\end{tabular} & \begin{tabular}{|l} 
Discipline \\
Punishments
\end{tabular} & Parents & \begin{tabular}{|l} 
Where family \\
reside
\end{tabular} & $\begin{array}{l}\text { Family } \\
\text { vehicle }\end{array}$ & \begin{tabular}{|l} 
Mother's \\
Salary
\end{tabular} & \begin{tabular}{|l|l|}
$\begin{array}{l}\text { Father's } \\
\text { Salary }\end{array}$ \\
\end{tabular} & $\begin{array}{l}\begin{array}{l}\text { Number of Brother / Sister } \\
\text { On (Primary School) }\end{array} \\
\end{array}$ & $\begin{array}{l}\text { Number of Brother } \\
\text { Sister On (High School) }\end{array}$ & $\begin{array}{l}\begin{array}{l}\text { Number of Brother } \\
\text { Sister On (University) }\end{array} \\
\end{array}$ \\
\hline Option 1 & & 0.69 & & 0.06 & 0.08 & & 0.03 & 0.03 & 0.03 & & \\
\hline \begin{tabular}{|l|} 
Option 2 \\
\end{tabular} & 0.249 & 0.10 & 0.09955 & 0.22 & 0.19 & \begin{tabular}{|l|l|}
0.17 \\
\end{tabular} & 0.07 & 0.07 & 0.07 & 0.07 & 0.07 \\
\hline Option 3 (alter & & 0.21 & & 0.72 & 0.72 & & 0.13 & 0.13 & 0.13 & 0.13 & \\
\hline 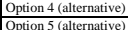 & & & & & & & $\frac{0.26}{0.50}$ & $\frac{0.26}{0.50}$ & \begin{tabular}{|l|l|l|l|l}
0.50 \\
\end{tabular} & $\frac{0.26}{0.50}$ & $\frac{0.26}{0.50}$ \\
\hline
\end{tabular}

Consistency Control for AHP

The following four-step procedure is used to check the consistency of the decision makers' 
Ç.Ü. Sosyal Bilimler Enstitüsü Dergisi, Cilt 28, Sayı 2, 2019, Sayfa 179-197

comparisons, showing an estimate of the weights of the decision makers indicated by $W$ (Winston, 2004). The consistency between the Consistency Index (CI) and the Consistency Rate is verified. Where $\lambda \max$ is the eigenvalue corresponding to the matrix of co-wise comparisons, and $\mathrm{n}$ is the number of elements being compared.

$$
C I=\frac{\lambda \max -\mathrm{n}}{\mathrm{n}-1} \text { The consistency rate }(\mathrm{CR}) \text { is defined as: } C R=\frac{C I}{R C I}
$$

Random consistency indices (RCI) are given in Table 9.

Table 9. Mean RCI values

\begin{tabular}{|l|c|c|c|c|c|c|c|c|c|c|}
\hline Number of Criteria (n) & 1 & 2 & 3 & 4 & 5 & 6 & 7 & 8 & 9 & 10 \\
\hline RCI & 0 & 0 & 0.58 & 0.90 & 1.12 & 1.24 & 1.32 & 1.41 & 1.45 & 1.49 \\
\hline
\end{tabular}

It is generally accepted that the CR value is below 0.1 . Otherwise, double comparative comparisons should be made in order to reduce the inconsistency. The values found for the consistency calculation are shown in Figure 6 and Figure 7.

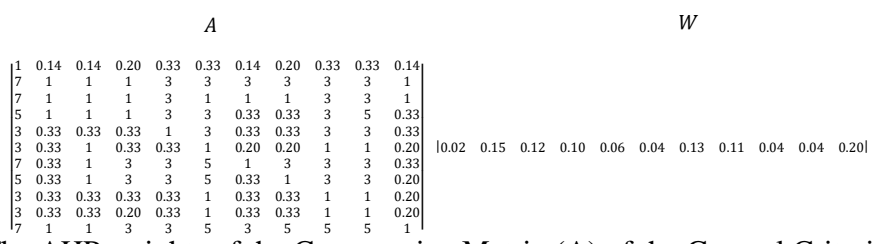

Figure 6. The AHP weights of the Comparative Matrix (A) of the General Criteria in Table 7

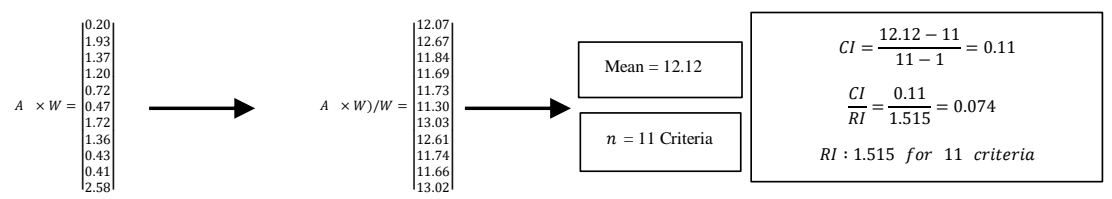

Figure 7. Consistency Calculation of CI / RI Value

When the $\frac{C I}{R I}$ value was found to be less than $0.074,0.10$, the comparative matrix of the criteria in Table 6 proved to be consistent. 


\section{Ç.Ü. Sosyal Bilimler Enstitüsü Dergisi, Cilt 28, Sayı 2, 2019, Sayfa 179-197}

\section{TOPSIS Method and Steps to be used}

TOPSIS is a method which is developed by Hwang and Yoon in 1981. This method is based on multi criteria decision making problem which is the nearest positive ideal solution $(\mathrm{A} *)$ and the ideal solution is the furthest negative ideal solution (A-) for selected alternatives. For example, a positive ideal solution maximizes functionality and minimizes cost while negative ideal solution maximizes cost and minimizes functionality. In the TOPSIS process, the performance ratings and the weights of the criteria are given as exact values (Lengacher \& Cammarata, 2012).The steps of the TOPSIS model are as follows (Tsaur, 2011):

Step 1: Create a decision matrix for the sequence. The weights of criteria and alternatives in FAHP are evaluated for each student according to the available data in Table 10.

Step 2: The decision matrix is normalized using the following equation. $e^{\prime}=\left[\frac{g_{j}\left(a_{i}\right)}{\sqrt{\sum_{i=1}^{m}\left(\left.g_{i}\left(a_{i}\right)\right|^{2}\right.}}\right] ; i=1,2$, $\ldots ., m ;$ and $\mathrm{j}=1,2, \ldots ., \mathrm{n}$

Step 3: The weighed normalized decision matrix is calculated by multiplying with the weights of the normalized decision matrix. $e_{i j}^{*}=\pi_{j} \times e_{i j}^{\prime} ; \mathrm{i}=1,2, \ldots, \mathrm{m}$; ve $\mathrm{j}=1,2, \ldots, \mathrm{n} \quad \pi_{j}$ is the weight of the $\mathrm{j}$ criteria.

Table 10. Evaluation table of weighted criteria and alternatives by FAHP

\begin{tabular}{|c|c|c|c|c|c|c|c|c|c|c|c|}
\hline Student Number & \begin{tabular}{|l|} 
Criteria I \\
\end{tabular} & Criteria 2 & Criteria 3 & Criteria 4 & Criteria 5 & \begin{tabular}{|l|l} 
Criteria 6 \\
\end{tabular} & \begin{tabular}{|l|} 
Criteria 7 \\
\end{tabular} & \begin{tabular}{|l|l|} 
Criteria 8 \\
\end{tabular} & Criteria 9 & Criteria 10 & \begin{tabular}{|l|} 
Criteria 11 \\
\end{tabular} \\
\hline Student 1 & \begin{tabular}{|l}
0.751 \\
\end{tabular} & \begin{tabular}{|l|l|}
0.69 \\
\end{tabular} & 0.90045 & & 0.72 & 0.17 & & \begin{tabular}{|l|l}
0.5 \\
\end{tabular} & 0 & & \\
\hline Student 2 & 0.751 & 0 & 0.90045 & 0.06 & 0.08 & 0.17 & 0.5 & \begin{tabular}{|l|}
0.26 \\
\end{tabular} & 0 & 0.07 & 0.13 \\
\hline Student 3 & 0.751 & 0.1 & 0.90045 & 0.72 & 0.08 & 0.17 & 0.26 & 0.26 & 0 & 0.07 & 0.03 \\
\hline Student 4 & 0.751 & \begin{tabular}{|l|l|}
0.1 \\
\end{tabular} & 0.90045 & 0.06 & 0.08 & 0.17 & 0.5 & \begin{tabular}{|l|l|}
0.26 \\
\end{tabular} & 0 & 0.07 & 0.03 \\
\hline $\begin{array}{l}\text { Student } 5 \\
\end{array}$ & 0.249 & 0 & 0.90045 & 0.06 & 0.72 & 0.83 & 0.5 & 0.07 & 0 & 0.03 & 0.03 \\
\hline $\begin{array}{l}\text { Student } 6 \\
\end{array}$ & 0.751 & 0 & 0.90045 & 0.06 & 0.08 & 0.17 & 0.5 & 0.5 & 0.03 & 0.07 & \\
\hline $\begin{array}{l}\text { Student } 7 \\
\end{array}$ & 0.751 & 0.69 & 0.90045 & 0.06 & 0.08 & 0.17 & 0.5 & \begin{tabular}{|l|}
0.07 \\
\end{tabular} & 0 & 0.03 & 0.07 \\
\hline $\begin{array}{l}\text { Student } 8 \\
\end{array}$ & 0.751 & 0 & 0.90045 & 0.06 & 0.08 & 0.17 & 0.5 & \begin{tabular}{|l|}
0.07 \\
\end{tabular} & 0 & 0 & 0.07 \\
\hline $\begin{array}{l}\text { Student } 9 \\
\end{array}$ & 0.751 & 0.69 & 0.90045 & 0.06 & 0.72 & 0.17 & 0.5 & 0.26 & 0 & 0 & 0 \\
\hline $\begin{array}{l}\text { Student } 10 \\
\end{array}$ & 0.751 & 0 & 0.90045 & 0.06 & 0.08 & 0.83 & 0.5 & \begin{tabular}{|l|l|}
0.07 \\
\end{tabular} & 0.03 & 0.03 & 0.03 \\
\hline $\begin{array}{l}\text { Student } 11 \\
\end{array}$ & 0.751 & 0 & 0.90045 & 0.06 & 0.72 & 0.17 & 0.5 & 0.26 & 0 & 0 & 0 \\
\hline $\begin{array}{l}\text { Student } 12 \\
\end{array}$ & 0.751 & 0.69 & 0.90045 & 0.06 & 0.72 & 0.17 & 0.5 & 0.5 & 0 & 0 & 0 \\
\hline $\begin{array}{l}\text { Student } 13 \\
\end{array}$ & 0.751 & 0 & 0.90045 & 0.06 & 0.19 & 0.17 & 0.5 & 0.26 & 0.03 & 0 & 0 \\
\hline $\begin{array}{l}\text { Student } 14 \\
\end{array}$ & 0.751 & 0 & 0.90 & 0.06 & 0.72 & 0.83 & 0.5 & 0.26 & 0.03 & 0 & 0 \\
\hline $\begin{array}{l}\text { Student } 15 \\
\end{array}$ & 0.751 & 0.69 & 0.90 & 0.06 & 0.08 & 0.17 & 0.5 & 0.26 & 0.03 & 0.03 & 0 \\
\hline $\begin{array}{l}\text { Student } 16 \\
\end{array}$ & 0.751 & \begin{tabular}{|l|l}
0.1 \\
\end{tabular} & 0.90045 & 0.06 & 0.08 & 0.17 & 0.5 & 0.07 & 0 & 0 & 0 \\
\hline $\begin{array}{l}\text { Student } 17 \\
\text { Suse }\end{array}$ & 0.751 & 0 & 0.90045 & 0.06 & 0.08 & 0.17 & 0.5 & 0.26 & 0.03 & 0 & 0.03 \\
\hline Student 18 & 0.751 & 0 & 0.900 & 0.06 & 0.08 & 0.17 & 0.26 & \begin{tabular}{|l|l|} 
& 0.26 \\
\end{tabular} & 0.03 & 0.03 & 0 \\
\hline Student 19 & 0.751 & 0 & 0.90045 & 0.06 & 0.08 & 0.17 & 0.5 & \begin{tabular}{|l|l|}
0.07 \\
\end{tabular} & 0 & 0.07 & 0 \\
\hline $\begin{array}{l}\text { Student } 20 \\
\text { Sol }\end{array}$ & 0.751 & \begin{tabular}{|l|l|}
0.1 \\
0.
\end{tabular} & 0.90045 & 0.06 & 0.08 & 0.17 & 0.5 & \begin{tabular}{|l|l|}
0.07 \\
0.26
\end{tabular} & 0 & 0 & 0 \\
\hline $\begin{array}{l}\text { Student } 21 \\
\text { St }\end{array}$ & 0.751 & \begin{tabular}{|l}
0 \\
\end{tabular} & 0.90045 & 0.06 & 0.08 & 0.83 & 0.5 & \begin{tabular}{|l|}
0.26 \\
0.07
\end{tabular} & 0 & 0 & 0 \\
\hline $\begin{array}{l}\text { Student } 22 \\
\text { Sutent } 23\end{array}$ & \begin{tabular}{|l|l}
0.751 \\
0.751 \\
\end{tabular} & \begin{tabular}{|l|l|}
0 \\
01
\end{tabular} & $\frac{0.90045}{0.90045}$ & 0.06 & 0.08 & \begin{tabular}{|l|}
0.17 \\
0.83 \\
\end{tabular} & \begin{tabular}{|l|}
0.5 \\
0.5 \\
\end{tabular} & \begin{tabular}{|l|}
0.07 \\
0.03 \\
\end{tabular} & $\frac{0}{0}$ & $\frac{0}{0}$ & $\frac{0}{0}$ \\
\hline Student 24 & 0.249 & 0 & 0.900045 & 0.06 & 0.08 & \begin{tabular}{|l}
.03 \\
0.17
\end{tabular} & \begin{tabular}{|l}
0.5 \\
0.5
\end{tabular} & \begin{tabular}{|l|l|}
0.26 \\
\end{tabular} & 0 & 0 & $\begin{array}{l}0 \\
0\end{array}$ \\
\hline $\begin{array}{l}\text { Student } 25 \\
\end{array}$ & 0.751 & 0 & 0.90045 & 0.06 & 0.08 & 0.83 & 0.5 & \begin{tabular}{|l|}
0.07 \\
\end{tabular} & 0 & 0 & 0 \\
\hline Student 26 & 0.751 & 0 & 0.90045 & 0.06 & 0.08 & 0.17 & 0.5 & 0.26 & 0 & 0 & 0 \\
\hline Student 27 & 0.249 & 0 & 0.90045 & 0.06 & 0.08 & 0.17 & 0.07 & \begin{tabular}{|l|}
0.07 \\
\end{tabular} & 0 & 0.03 & 0 \\
\hline $\begin{array}{l}\text { Student } 28 \\
\end{array}$ & 0.751 & 0 & 0.90045 & 0.06 & 0.08 & 0.17 & 0.5 & \begin{tabular}{|l|}
0.26 \\
\end{tabular} & 0 & 0 & 0 \\
\hline
\end{tabular}


Ç.Ü. Sosyal Bilimler Enstitüsü Dergisi, Cilt 28, Sayı 2, 2019, Sayfa 179-197

Step 4: Positive ideal solution (A *) and negative ideal solution (A -) are determined.

Positive; $\quad A^{*}=\left\{e_{i}^{j}, J=1,2, \ldots, n\right\}=\left\{e_{1}^{*}, e_{1}^{*}, \ldots, e_{1}^{*}\right\} ; \quad e_{j}^{*}=\operatorname{Max}_{i}\left\{e_{i j}^{\prime \prime}\right\} \quad A^{*}-=\left\{\operatorname{Min}_{i} \cdot e_{i j}^{*}, i=1, \ldots, m ; v e j=\right.$ $1, \ldots, n\}$

Negative; $\quad A-=\left\{\operatorname{Min}_{i} e_{i j}^{\prime \prime}, i=1, \ldots, m ;\right.$ ve $\left.j=1, \ldots, n\right\} ; \quad e_{j^{*}}=\operatorname{Min}_{i}\left\{e_{i j}^{\prime \prime}\right\} \quad A-=\left\{e_{j^{*}}, j=1,2, \ldots, n\right\}=$ $\left\{e_{1^{*}}, e_{2^{*}}, \ldots, e_{n^{*}}\right\}$

Step 5: Euclidean distances of each alternative are determined from the positive and negative ideal solutions.

Table 11. The square root of the column totals of the squares of the criteria values

$$
\begin{aligned}
& D_{i}^{j} \sqrt{\sum_{1}^{n}\left(e_{i j}^{*}-e_{j}^{*}\right)^{2}, \quad i=1,2, \ldots, m}=\quad D_{i}^{-} \sqrt{\sum_{1}^{n}\left(e_{i j}^{*}-e_{j^{*}}\right)^{2}, \quad i=1,2, \ldots, m}= \\
& \begin{array}{|l|l|l|l|l|l|l|l|l|l|l|}
\hline \text { Criteria } 1 & \text { Criteria } 2 & \text { Criteria } 3 & \text { Criteria 4 } & \text { Criteria 5 } & \text { Criteria 6 } & \text { Criteria 7 } & \text { Criteria 8 } & \text { Criteria 9 } & \text { Criteria 10 } & \text { Criteria 11 } \\
\hline 3.78 & 1.56 & 4.76 & 0.78 & 1.81 & 2.18 & 2.48 & 1.32 & 0.08 & 0.19 & 0.18 \\
\hline
\end{array}
\end{aligned}
$$

In Table 12, the values obtained by multiplying the values in Table 11 with the criterial weights are given.

\begin{tabular}{|c|c|c|c|c|c|c|c|c|c|c|c|}
\hline & \begin{tabular}{|l|} 
Criteria 1 \\
\end{tabular} & Criteria 2 & Criteria 3 & \begin{tabular}{|l|l|} 
Criteria 4 \\
\end{tabular} & $\begin{array}{l}\text { Criteria } 5 \\
\end{array}$ & $\begin{array}{ll}\text { Criteria } 6 \\
\end{array}$ & $\begin{array}{ll}\text { Criteria } 7 \\
\end{array}$ & Criteria 8 & \begin{tabular}{|l|} 
Criteria 9 \\
\end{tabular} & \begin{tabular}{|l|} 
Criteria 10 \\
\end{tabular} & \begin{tabular}{|l} 
Criteria 11 \\
\end{tabular} \\
\hline Criteria Weights in FAHP & 0 & 0.18 & 0.1 & \begin{tabular}{|l|l|}
0.11 \\
\end{tabular} & 0.01 & 0 & 0.19 & 0.14 & 0 & & \\
\hline Student 1 & 0.00000 & $\begin{array}{l}0.07967 \\
\end{array}$ & 0.01890 & \begin{tabular}{|l|}
0.00841 \\
\end{tabular} & 0.00397 & 0.00000 & 0.00995 & 0.05297 & 0.00000 & $\begin{array}{ll}0.00000 \\
\end{array}$ & 0.04521 \\
\hline Student 2 & 0.00000 & 0.00000 & 0.01890 & \begin{tabular}{|l|}
0.00841 \\
\end{tabular} & & & 0.03829 & 0.02754 & & \begin{tabular}{|l|}
0.00000 \\
\end{tabular} & \\
\hline Student 3 & 0.00000 & & 0.01890 & & & 0.00000 & 0.01991 & & & 0.00000 & \\
\hline Student 4 & 0.00000 & & 0.01890 & 0.00841 & 0.00044 & 0.00000 & & 0.02754 & & & \\
\hline Student 5 & 0.00000 & 0.00000 & 0.01890 & 0.00841 & 0.00397 & 0.00000 & 0.03829 & 0.00742 & 0.00000 & 0.00000 & 0.04521 \\
\hline Student 6 & 0.00000 & 0.00000 & 0.01890 & \begin{tabular}{|l|}
0.00841 \\
\end{tabular} & 0.00044 & 0.00000 & 0.03829 & 0.05297 & 0.00000 & 0.00000 & 0.00000 \\
\hline Student 7 & 0.00000 & 0.07967 & 0.01890 & \begin{tabular}{|l|}
0.00841 \\
\end{tabular} & 0.00044 & 0.00000 & 0.03829 & 0.00742 & 0.00000 & 0.00000 & 0.10549 \\
\hline Student 8 & 0.00000 & 0.00000 & 0.01890 & \begin{tabular}{|l|}
0.00841 \\
\end{tabular} & 0.00044 & 0.00000 & 0.03829 & 0.00742 & 0.00000 & 0.00000 & 0.10549 \\
\hline Student 9 & 0.00000 & 0.07967 & 0.01890 & 0.00841 & 0.00397 & 0.00000 & 0.03829 & 0.02754 & 0.00000 & 0.00000 & 0.00000 \\
\hline Student 10 & 0.00000 & 0.00000 & 0.01890 & \begin{tabular}{|l|l|}
0.00841 \\
\end{tabular} & 0.00044 & 0.00000 & 0.03829 & 0.00742 & 0.00000 & \begin{tabular}{|l|}
0.00000 \\
\end{tabular} & 0.04521 \\
\hline Student 11 & 0.00000 & 0.00000 & 0.01890 & \begin{tabular}{|l|}
0.00841 \\
\end{tabular} & 0.00397 & 0.00000 & 0.03829 & 0.02754 & 0.00000 & \begin{tabular}{|l|}
0.00000 \\
\end{tabular} & 0.00000 \\
\hline Student 12 & 0.00000 & $\begin{array}{l}0.07967 \\
\end{array}$ & 0.01890 & \begin{tabular}{|l|}
0.00841 \\
\end{tabular} & 0.00397 & 0.00000 & 0.03829 & 0.05297 & 0.00000 & \begin{tabular}{|l|}
0.00000 \\
\end{tabular} & 0.00000 \\
\hline Student 13 & 0.00000 & 0.00000 & 0.01890 & \begin{tabular}{|l|l|}
0.00841 \\
\end{tabular} & 0.00105 & 0.00000 & 0.03829 & 0.02754 & \begin{tabular}{|l|l|}
0.00000 \\
\end{tabular} & \begin{tabular}{|l|}
0.00000 \\
\end{tabular} & 0.00000 \\
\hline Student 14 & 0.00000 & 0.00000 & 0.01890 & 0.00841 & 0.00397 & 0.00000 & 0.03829 & 0.02754 & \begin{tabular}{|l|l} 
\\
\end{tabular} & 0.00000 & 0.00000 \\
\hline Student 15 & 0.00000 & $\begin{array}{l}0.07967 \\
\end{array}$ & $\begin{array}{l}0.01890 \\
\end{array}$ & \begin{tabular}{|l|}
0.00841 \\
\end{tabular} & 0.00044 & 0.00000 & 0.03829 & $\begin{array}{l}0.02754 \\
\end{array}$ & \begin{tabular}{|l|}
0.00000 \\
\end{tabular} & \begin{tabular}{|c|}
0.00000 \\
\end{tabular} & 0.00000 \\
\hline Student 16 & 0.00000 & 0.01155 & $\begin{array}{l}0.01890 \\
\end{array}$ & \begin{tabular}{|l|l|}
0.00841 \\
\end{tabular} & 0.00044 & 0.00000 & 0.03829 & 0.00742 & \begin{tabular}{|l|l|}
0.00000 \\
\end{tabular} & \begin{tabular}{|l|l|}
0.00000 \\
\end{tabular} & 0.00000 \\
\hline Student 17 & 0.00000 & 0.00000 & 0.01890 & \begin{tabular}{|l}
0.00841 \\
\end{tabular} & 0.00044 & 0.00000 & 0.03829 & 0.02754 & 0.00000 & \begin{tabular}{|l}
0.00000 \\
\end{tabular} & 0.04521 \\
\hline Student 18 & 0.000000 & 0.00000 & 0.01890 & \begin{tabular}{|l|}
0.00841 \\
\end{tabular} & 0.00044 & 0.00000 & 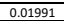 & 0.02754 & \begin{tabular}{|l}
0.00000 \\
\end{tabular} & 0.00000 & 0.00000 \\
\hline Student 19 & 0.000000 & 0.00000 & 0.01890 & \begin{tabular}{|l|}
0.00841 \\
\end{tabular} & 0.00044 & 0.00000 & 0.03829 & 0.00742 & 0.00000 & \begin{tabular}{|l|l}
0.00000 \\
\end{tabular} & 0.00000 \\
\hline Student 20 & 0.00000 & 0.01155 & 0.01890 & \begin{tabular}{|l|}
0.00841 \\
\end{tabular} & 0.00044 & 0.00000 & 0.03829 & 0.00742 & 0.00000 & 0.00000 & 0.00000 \\
\hline Student 21 & \begin{tabular}{|l}
0.00000 \\
\end{tabular} & 0.00000 & 0.01890 & \begin{tabular}{|l|}
0.00841 \\
\end{tabular} & 0.00044 & 0.00000 & 0.03829 & 0.02754 & \begin{tabular}{|l|l|}
0.00000 \\
\end{tabular} & \begin{tabular}{|c|}
0.00000 \\
\end{tabular} & 0.00000 \\
\hline Student 22 & 0.000000 & 0.00000 & 0.01890 & \begin{tabular}{|l}
0.00841 \\
\end{tabular} & 0.00044 & 0.00000 & 0.03829 & 0.00742 & \begin{tabular}{|l|l|}
0.00000 \\
\end{tabular} & \begin{tabular}{|l|}
0.00000 \\
\end{tabular} & 0.00000 \\
\hline Student 23 & 0.00000 & 0.01155 & 0.01890 & \begin{tabular}{|l|l|}
0.00841 \\
\end{tabular} & 0.00044 & 0.00000 & 0.03829 & 0.00318 & \begin{tabular}{|l}
0.00000 \\
\end{tabular} & \begin{tabular}{|l}
0.00000 \\
\end{tabular} & 0.00000 \\
\hline Student 24 & $\begin{array}{l}0.00000 \\
\end{array}$ & 0.00000 & 0.01890 & \begin{tabular}{|l|}
0.00841 \\
\end{tabular} & 0.00044 & 0.00000 & 0.03829 & 0.02754 & \begin{tabular}{|l|l}
0.00000 \\
\end{tabular} & \begin{tabular}{|l|l}
0.00000 \\
\end{tabular} & 0 \\
\hline Student 25 & $\begin{array}{l}0.00000 \\
\end{array}$ & 0.00000 & 0.01890 & \begin{tabular}{|l|}
0.00841 \\
\end{tabular} & 0.00044 & 0.00000 & 0.03829 & 0.00742 & \begin{tabular}{|l|l|}
0.00000 \\
\end{tabular} & \begin{tabular}{|l|}
0.00000 \\
\end{tabular} & 0.00000 \\
\hline Student & 0.00000 & 0.00000 & 0.01890 & \begin{tabular}{|l|}
0.00841 \\
\end{tabular} & 0.00044 & 0.00000 & 0.03829 & 0.02754 & 0.00000 & \begin{tabular}{|l}
0.00000 \\
\end{tabular} & 0.00000 \\
\hline Student 27 & $\begin{array}{l}0.00000 \\
\end{array}$ & 0.00000 & 0.01890 & \begin{tabular}{|l|}
0.00841 \\
\end{tabular} & 0.00044 & 0.00000 & 0.00536 & 0.00742 & \begin{tabular}{|l|l|}
0.00000 \\
\end{tabular} & \begin{tabular}{|l}
0.00000 \\
\end{tabular} & 0.00000 \\
\hline $\begin{array}{l}\text { Student } 28 \\
\end{array}$ & $\begin{array}{l}0.00000 \\
\end{array}$ & 0.00000 & 0.01890 & \begin{tabular}{|l|}
0.00841 \\
\end{tabular} & 0.00044 & 0.00000 & 0.03829 & 0.02754 & \begin{tabular}{|l|l|}
0.00000 \\
\end{tabular} & \begin{tabular}{|l|}
0.00000 \\
\end{tabular} & 0.00000 \\
\hline
\end{tabular}

Table 12. The multiplication of the criterial weights and the values in Table 11

In Table 12, each cell is subtracted from the ideal solution value in its column and squared. The sum of each line is taken and the square root of this total gives us the ideal distance value of $\mathrm{Si}$. The same process is performed for the ideal solution value and the 
Ç.Ü. Sosyal Bilimler Enstitüsü Dergisi, Cilt 28, Sayı 2, 2019, Sayfa 179-197

negative value of $\mathrm{Si}$ is found.

Table 13. + Ideal solution value and - Ideal solution value

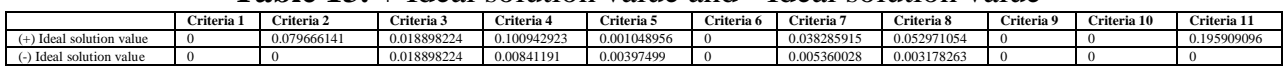

Step 6: Using the following equation, the relative proximity coefficient of i alternatives for ideal solution is calculated.
$c_{i}^{*}=\frac{D_{i}^{-}}{D_{i}^{*}+D_{i}^{-}}$,
$i=1,2, \ldots, m$
$0 \leq c i^{*} \leq 1$

Step 7: All alternatives are arranged based on the decreasing values of $c_{i}^{*}$ and the optimal choices.

Table 14. $c_{i}^{*}$ calculation table

\begin{tabular}{|c|c|c|c|}
\hline & square root $\left(D_{i}^{*}\right.$, Ideal Distance $)$ & square root $\left(D_{i}^{-}\right.$, Negative Ideal Distance) & $\frac{c_{i}^{*}}{c_{0}}$ \\
\hline Student 1 & 0.1791187 & 0.104360189 & 0.368140955 \\
\hline $\begin{array}{l}\text { Student } 2 \\
\end{array}$ & 0.1247218 & 0.200176691 & 0.616120635 \\
\hline & & & \\
\hline $\begin{array}{ll}\text { Student } 4 \\
\end{array}$ & 0.1912054 & 0.062189749 & \\
\hline Student 5 & 0.1992556 & 0.05608919 & 0.219660605 \\
\hline Student 6 & 0.2308450 & 0.059799 & 0.205746532 \\
\hline Student 7 & 0.1371617 & 0.136342539 & 0.498502512 \\
\hline $\begin{array}{ll}\text { Student } 8 \\
\end{array}$ & 0.1586191 & 0.110646255 & 0.410919012 \\
\hline Student 9 & 0.2181683 & 0.089579816 & 0.291081599 \\
\hline Student 10 & 0.1992350 & 0.05620037 & 0.220017934 \\
\hline Student 11 & 0.2322587 & 0.040961559 & 0.149921382 \\
\hline Student 12 & 0.2166816 & 0.099549636 & 0.314800118 \\
\hline Student 13 & 0.2322403 & 0.041065935 & 0.150256138 \\
\hline $\begin{array}{ll}\text { Student } 14 \\
\end{array}$ & 0.2322587 & 0.040961559 & 0.149921382 \\
\hline Student 15 & 0.2181495 & 0.089649472 & 0.291259787 \\
\hline Student 16 & 0.2316428 & 0.035325094 & 0.132319644 \\
\hline Student 17 & 0.1956165 & 0.061108583 & 0.238031206 \\
\hline Student 18 & 0.2329670 & 0.028598651 & 0.109336407 \\
\hline Student 19 & 0.2352970 & 0.033384972 & 0.12425459 \\
\hline Student 20 & 0.2316428 & 0.035325094 & 0.132319644 \\
\hline Student 21 & 0.2322411 & 0.041113668 & 0.150404085 \\
\hline Student 22 & 0.2352970 & 0.033384972 & 0.12425459 \\
\hline Student 23 & 0.2325133 & 0.035069991 & 0.131061966 \\
\hline Student 24 & 0.2322411 & 0.041113668 & 0.150404085 \\
\hline Student 25 & 0.2352970 & 0.033384972 & 0.12425459 \\
\hline Student 26 & 0.2322411 & 0.041113668 & 0.150404085 \\
\hline Student 27 & 0.2375896 & 0.005517458 & 0.022695593 \\
\hline Student 28 & 0.2322411 & 0.041113668 & 0.150404085 \\
\hline
\end{tabular}

Table 14 contains the square root of $D_{i}^{*}$ ideal distance and $D_{i}^{-}$negative ideal distance values. The values of $c_{i}^{*}$ calculated according to the formula of $c_{i}^{*}=\frac{D_{i}^{-}}{D_{i}^{*}+D_{i}^{-}} \quad$ are in Table 14 .

\section{Conclusion}

The scores of 37 students who applied for the posts of 'computer maintenance' (1 student) and 'using certain software, updating, and taking pictures' ( 1 student) advertised by Cukurova 


\section{Ç.Ü. Sosyal Bilimler Enstitüsü Dergisi, Cilt 28, Sayı 2, 2019, Sayfa 179-197}

University Department of Health, Culture and Sports based on Existing Scoring System are given in Table 15.

The students who appear in Table 15 are the part of the students ranked according to the existing scoring system and FAHP - TOPSIS system according to the answers given by the students to the general criteria questions at the 1st request of Unit. The results are different from FAHP and TOPSIS from the current scoring system; therefore, this may lead to changes in sequence. In this table, the scores for students who apply to work for Health, Culture and Sports Department by using the results of table 7 and table 8 are calculated and ranked by TOPSIS.

Table 15. According to the General Criteria, students who have been selected and ranked by existing scoring system and students who are ranked by FAHP and TOPSIS

\begin{tabular}{|c|c|c|c|}
\hline \multicolumn{2}{|c|}{ Current Score and Ranking } & \multicolumn{2}{|c|}{ Calculation and Sorting with FAHP and TOPSIS } \\
\hline Point & Student Number & Student Number & Point \\
\hline 26 & Student 1 & Student 2 & 0.616120635 \\
\hline 23 & Student 2 & Student 7 & 0.498502512 \\
\hline 22 & Student 3 & Student 8 & 0.410919012 \\
\hline 22 & Student 4 & Student 3 & 0.389740534 \\
\hline 20 & Student 5 & Student 1 & 0.368140955 \\
\hline 20 & Student 6 & Student 12 & 0.314800118 \\
\hline 19,5 & Student 7 & Student 15 & 0.291259787 \\
\hline 19,5 & Student 8 & Student 9 & 0.291081599 \\
\hline 19 & Student 9 & Student 4 & 0.24542597 \\
\hline 19 & Student 10 & Student 17 & 0.238031206 \\
\hline 19 & Student 11 & Student 10 & 0.220017934 \\
\hline 18,5 & Student 12 & Student 5 & 0.219660605 \\
\hline 18 & Student 13 & Student 6 & 0.205746532 \\
\hline 18 & Student 14 & Student 28 & 0.150404085 \\
\hline 18 & Student 15 & Student 26 & 0.150404085 \\
\hline 17,5 & Student 16 & $\begin{array}{l}\text { Student } 24 \\
\end{array}$ & 0.150404085 \\
\hline 17,5 & Student 17 & Student 21 & 0.150404085 \\
\hline 17 & Student 18 & Student 13 & 0.150256138 \\
\hline 17 & Student 19 & Student 14 & 0.149921382 \\
\hline 17 & Student 20 & $\begin{array}{l}\text { Student } 11 \\
\end{array}$ & 0.149921382 \\
\hline 17 & Student 21 & Student 20 & 0.132319644 \\
\hline 16,5 & Student 22 & Student 16 & 0.132319644 \\
\hline 16,5 & $\begin{array}{l}\text { Student } 23 \\
\end{array}$ & $\begin{array}{l}\text { Student } 23 \\
\end{array}$ & 0.131061966 \\
\hline 16 & $\begin{array}{l}\text { Student } 24 \\
\end{array}$ & Student 25 & 0.12425459 \\
\hline 16 & Student 25 & Student 22 & 0.12425459 \\
\hline 15,5 & Student 26 & Student 19 & 0.12425459 \\
\hline 15 & Student 27 & Student 18 & 0.109336407 \\
\hline 15 & Student 28 & Student 27 & 0.022695593 \\
\hline
\end{tabular}

Criteria used in FAHP and TOPSIS implementations were compared with each other according to their significance levels. If this comparison was consistent, calculations were made according to the alternative corresponding values of the parameters. Evaluation of participants determined by using these parameters that is calculated by different student 
Ç.Ü. Sosyal Bilimler Enstitüsü Dergisi, Cilt 28, Sayı 2, 2019, Sayfa 179-197

specifications can be made more fairly. A numerical value is obtained for each criteria and their alternatives by using FAHP. The results which are obtained by using this method are much better than the current method used for selecting the most suitable applicants who are different from each other.

A student who has more than $10.000 \mathrm{TL}$ monthly revenue and 2 brothers / sisters in university has an advantage over another student who has less than 1000 TL monthly revenue and no brothers / sisters in the current scoring system. In this new system, these problems can be eliminated by weighing among criteria.

In this study, the methods used for selecting part-time students are aimed to be conducted more fairly. The part-time student module is encoded in the asp (active server page) language at the relevant internet address of the unit. The current method was not effective since the criteria used were not related with each other. In this developed system, correlation degree of each criteria with the other criteria was compared and weighed by applying the FAHP and TOPSIS method. Alternatives related with criteria are also weighed by using this method. These weights are applied for the request which contains " 1 student for computer maintenance related to Health, Culture and Sports Department, and 1 student (2 students in total) to use certain software, update and take pictures".

In this developed new software, new criteria and new alternatives for these criteria can be added. Therefore, this system can be useful for health, culture and sports departments of the other universities as well. Each unit can compare and change general criteria and their weights consistent with each other in their human resources departments.

This new software and database can be integrated with the other multi-criteria decision-making techniques and the results can be compared with each other. By this way, a wide range of data can be gathered for choosing the right decision-making technique.

\section{References}

Anık, Z. (2007, Haziran). Nesne Yönelimli Yazılım Dillerinin Analitik Hiyerarşi Ve Analitik Network Prosesi İle Karşılaştırılması Ve Değerlendirilmesi. Gazi Üniversitesi Fen Bilimleri Enstitüsü.

Ayhan, M. B. (2013). A Fuzzy Ahp Approach For Supplier Selection Problem: A Case Study In A Gearmotor Company. International Journal of Managing Value and Supply Chains, 4(3), 11-23. doi:10.5121/ijmvsc.2013.4302 
Ç.Ü. Sosyal Bilimler Enstitüsü Dergisi, Cilt 28, Sayı 2, 2019, Sayfa 179-197

Chang, D. Y. (1996). Applications Of The Extent Analysis Method On Fuzzy AHP. European Journal of Operational Research, 4(7), 649-655. doi:10.1016/j.ejor.2007.01.050

Erdoğan, İ. (1991). İşletmelerde Personel Seçimi ve Başarı Değerleme Teknikleri. İstanbul: İşletme İktisadı Enstitüsü Yayınları.

Felek, S., Yurdakul, Y., \& Aladağ, Z. (2007). Mobil Iletişim Sektöründe Pazar Paylaşiminin Tahmininde Ahp Ve Anp Yöntemlerinin Kiyaslamasi. Endüstri Mühendisliği Dergisi, 18(1), 6-22.

Fülop, J. (2019, March 21). Introduction to Decision Making Methods. semanticscholar.org: https://pdfs.semanticscholar.org/e0d8/d4fd210c4aeae40560c7332711c7cc8dc5df.p df adresinden alınd 1

Laarhoven, V. (1983). A Fuzzy Extension Of Saaty"s Priority Theory. Fuzzy Sets and Systems, 1(11), 199-227. doi:10.1016/S0165-0114(83)80082-7

Lengacher, D., \& Cammarata, C. (2012). A Two-Phase Data Envelopment Analysis Model for Portfolio Selection. Advances in Decision Sciences, 1-9. doi:10.1155/2012/869128

Saaty, T. L., \& Vargas, L. G. (2001). Models, Methods, Concepts \& Applications of The Analytic Hierarchy Process. New York: Springer.

Tsaur, R. C. (2011). Decision Risk Analysis For An Interval TOPSIS Method. Applied Mathematics and Computation, 8(218), 4295-4304. doi:10.1016/j.amc.2011.10.001

Winston, W. L. (2004). Operations Research: Applications and Algorithms (4. b.). Canada: Thomson Learning. 
Ç.Ü. Sosyal Bilimler Enstitüsü Dergisi, Cilt 28, Sayı 2, 2019, Sayfa 179-197
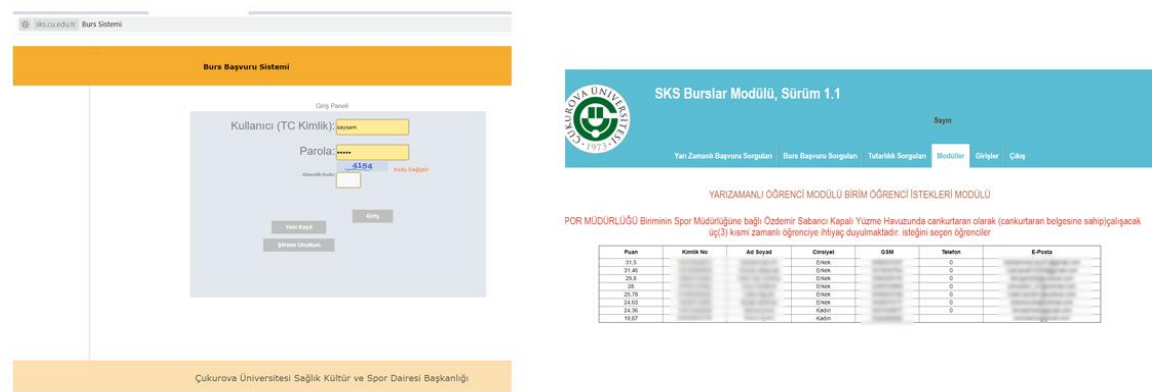

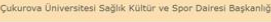

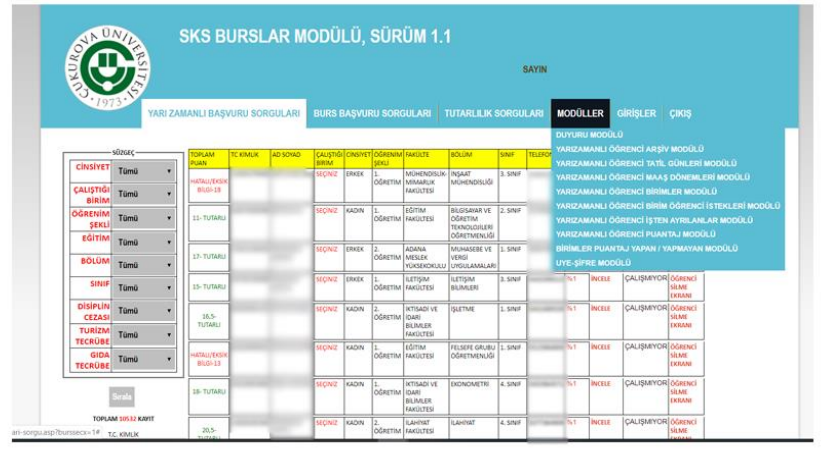

Figure $2:$ Images from this developed software 